\title{
Thoracic Pedicle Morphometry of Dry Vertebral Columns in Relation to Trans-Pedicular Fixation: A Cross-Sectional Study From Central India
}

Virendra Verma ${ }^{1}$, John A. Santoshi ${ }^{1}$, Vaibhav Jain ${ }^{1}$, Manmohan Patel ${ }^{2}$, Manish Dwivedi ${ }^{1}$, Manoj Nagar ${ }^{1}$ , Rajkumar Selvanayagam ${ }^{1}$, Dharm Pal ${ }^{1}$

1. Orthopaedics, All India Institute of Medical Sciences, Bhopal, IND 2. Anatomy, All India Institute of Medical Sciences, Bhopal, IND

Corresponding author: Vaibhav Jain, vaibhavigmc@gmail.com

\section{Abstract}

\section{Introduction}

Trans-pedicular screw fixation is one of the main modalities of spinal instrumentation today. It is particularly challenging in the thoracic spine due to the narrow pedicle dimensions especially in the upper and mid-thoracic levels. We aimed to study the anatomical variations like pedicle dimensions and angulation in transverse and sagittal planes.

\section{Material and methods}

We conducted an anatomical investigation on 20 dry vertebral columns (14 male and six female), from T1 to T12 levels. The measurements included pedicle width, height, and transverse and sagittal angles of the pedicle. Numerical variables were summarized using mean and standard deviation.

\section{Results}

T12 vertebra was found to have the widest pedicle width (mean $7.89 \pm 0.70 \mathrm{~mm}$ ) and the widest pedicle height (mean $15.45 \pm 0.78 \mathrm{~mm}$ ) while T5 vertebra (mean $3.65 \pm 0.40 \mathrm{~mm}$ ) had the narrowest pedicle width. T1 vertebra had the maximum transverse angle of the pedicle (mean $30.37 \pm 2.56$ degree); whereas, $T 2$ vertebra had the maximum sagittal angle (mean $19.22 \pm 2.24$ degree).

\section{Conclusion}

We have reported detailed pedicle measurements including their angulation for the thoracic spine in dry vertebral columns of central India. The pedicles are directed more medially from T1 to T10 levels and are almost neutral at T11 and T12 levels. These findings would not only be of immense help to the spinal surgeons but also help in designing implants and instrumentations specific for the thoracic spine for the central Indian population as well as aiding surgeons to perform more precise and, therefore, safe surgical procedures.

Received 04/30/2020

Review began 05/07/2020 Review ended 05/07/2020 Published 05/16/2020

\section{() Copyright 2020}

Verma et al. This is an open access article distributed under the terms of the Creative Commons Attribution License CC-BY 4.0., which permits unrestricted use, distribution, and reproduction in any medium, provided the original author and source are credited.
Categories: Neurosurgery, Orthopedics, Anatomy

Keywords: pedicle morphometry, spine, thoracic, instrumentation, pedicle screw, india

\section{Introduction}

Pedicles of the vertebrae are the short, thick, cylindrical bony processes that project posteriorly from the superior part of the vertebral body and fuse with the laminae to form the neural arch. These are situated between the transverse process and the spinous process. In the thoracic spine, the spinal cord and segmental nerves constitute the content of the spinal canal. The contents of the spinal canal are at risk of injury during spinal instrumentation.

Earlier, laminar hooks and sublaminar wires were used for spinal instrumentation. These had lesser strength and carried the risk of encroachment into the spinal canal as they held the lamina for fixation to the spine. Posterior spinal instrumentation through pedicles has been utilized for the past six decades [1]. Theoretically, with the use of pedicle screws, which are placed into the vertebral body through the pedicles, there is no invasion into the spinal canal and the fixation strength is greater [2]. The posterior spinal instrumentation through pedicles is frequently used for the management of vertebral fractures, degenerative spine, spondylolisthesis and correction of deformity [1]. They can also be used postlaminectomy where laminar hooks and sublaminar wires cannot be used. Pedicle screw malpositioning has resulted in complications like pedicle penetration, fracture of pedicle, neurological irritation and cerebrospinal fluid leakage. To prevent these complications, precise screw positioning is of prime importance. The surgeons contemplating pedicle screw fixation need to have a thorough knowledge of the 


\section{Cureus}

spinal anatomy and should be able to identify and localize bony as well as neural structures precisely. This requires a combination of directly visualized bony anatomy, proprioceptive feedback, preoperative planning, and intraoperative radiological imaging [1-5].

Racial variations in pedicle morphology in different ethnic groups and populations are well documented as are the differences between males and females [6-8]. The standard pedicle screws are available from $4.5 \mathrm{~mm}$ to $8 \mathrm{~mm}$ diameter and are based on the morphometric analysis of the Caucasian population. Since variation in pedicle morphology could affect the quality of fixation and possible risk of complications, it would be of great interest to determine if the available screws are suitable for the central Indian population. We aimed to study the anatomical variations like pedicle dimensions and angulation in transverse and sagittal plane to facilitate safe pedicle screw insertion in the thoracic spine while preventing neurological complications.

\section{Materials And Methods}

We performed an anatomic investigation on the dry vertebral column after institutional research and review board approval. Twenty adult dry vertebral columns (14 male and six female) were available for the study. All the vertebral columns were free of prior trauma or visible deformity. The morphometric measurements with respect to dimensions of pedicles of thoracic vertebrae were done. The measurements included pedicle width (transverse external diameter), pedicle height (sagittal external diameter), transverse and sagittal angles of the pedicle [9]. The measurements were performed by using Vernier calipers and standard goniometer. The narrowest transverse external diameter of the pedicle was recorded at the pedicle width (Figure 1). The narrowest sagittal external diameter of the pedicle was recorded as the pedicle height (Figure 2). The transverse angle of pedicles was defined as the angle between the pedicle axis and a line parallel to the vertebral midline measured in the transverse plane (Figure 3). The sagittal angle of the pedicle was defined as the angle between the pedicle axis and the superior border of the vertebral body in the sagittal plane (Figure 4).

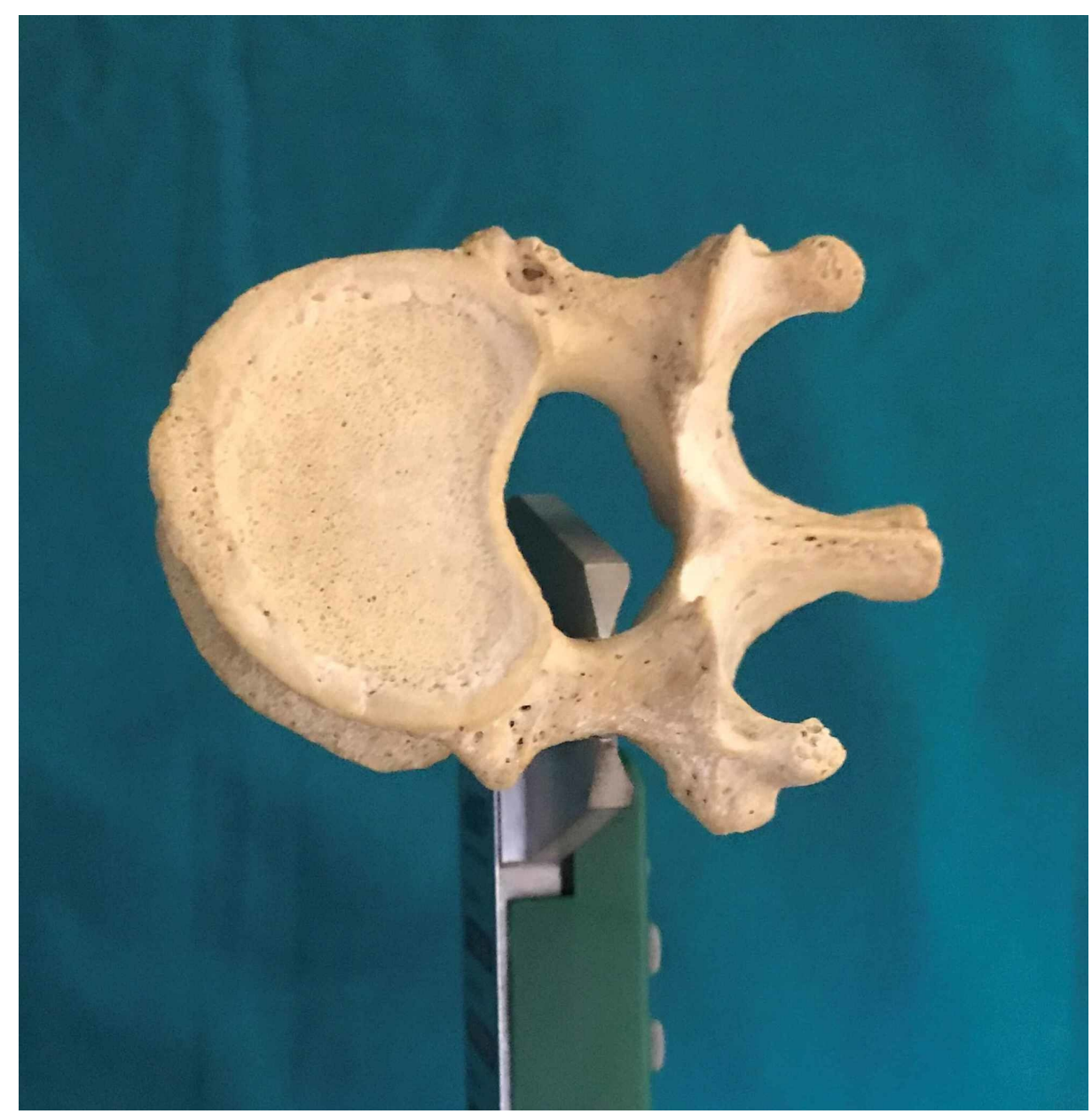

FIGURE 1: Pedicle width 


\section{Cureus}

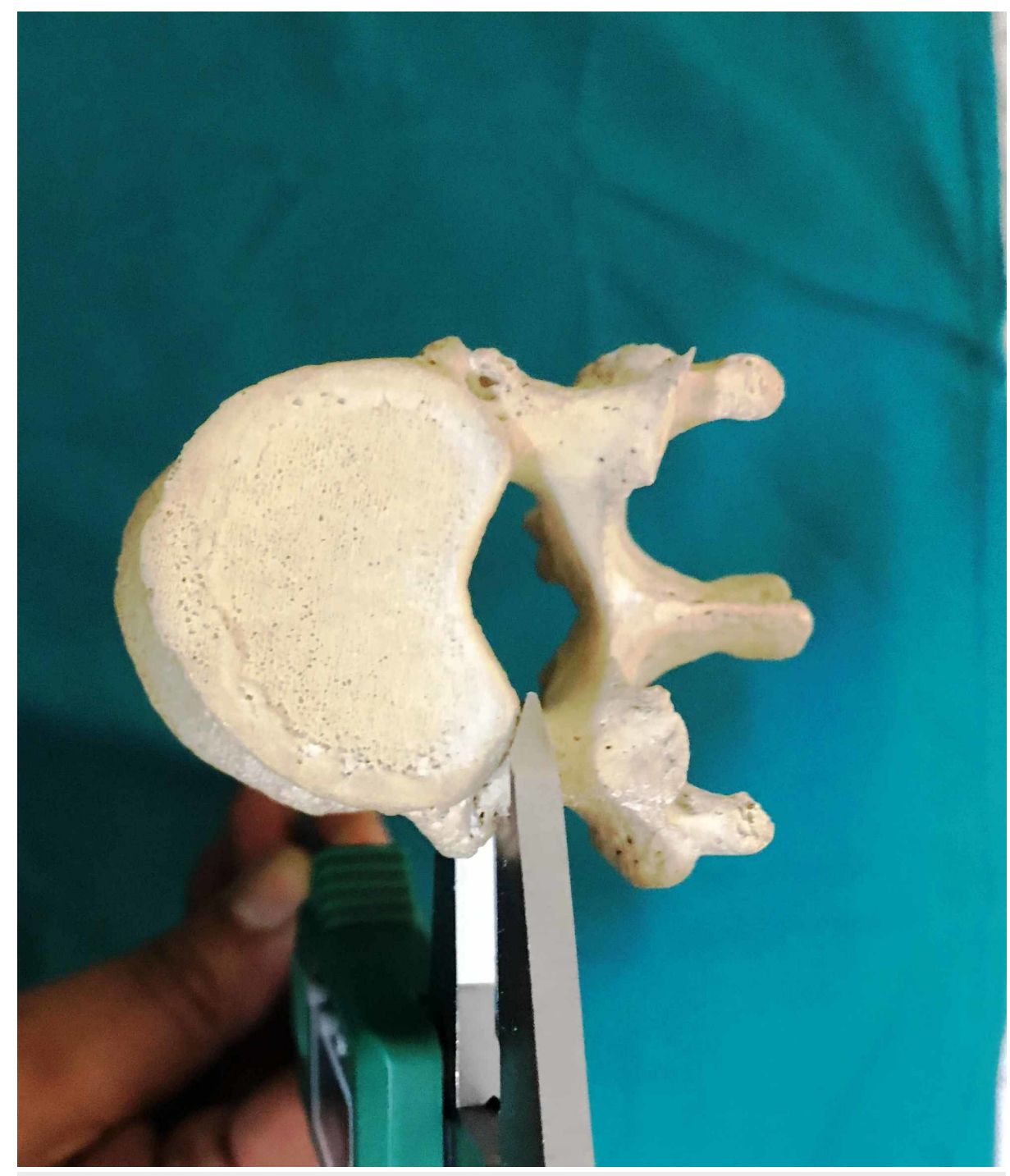

FIGURE 2: Pedicle height

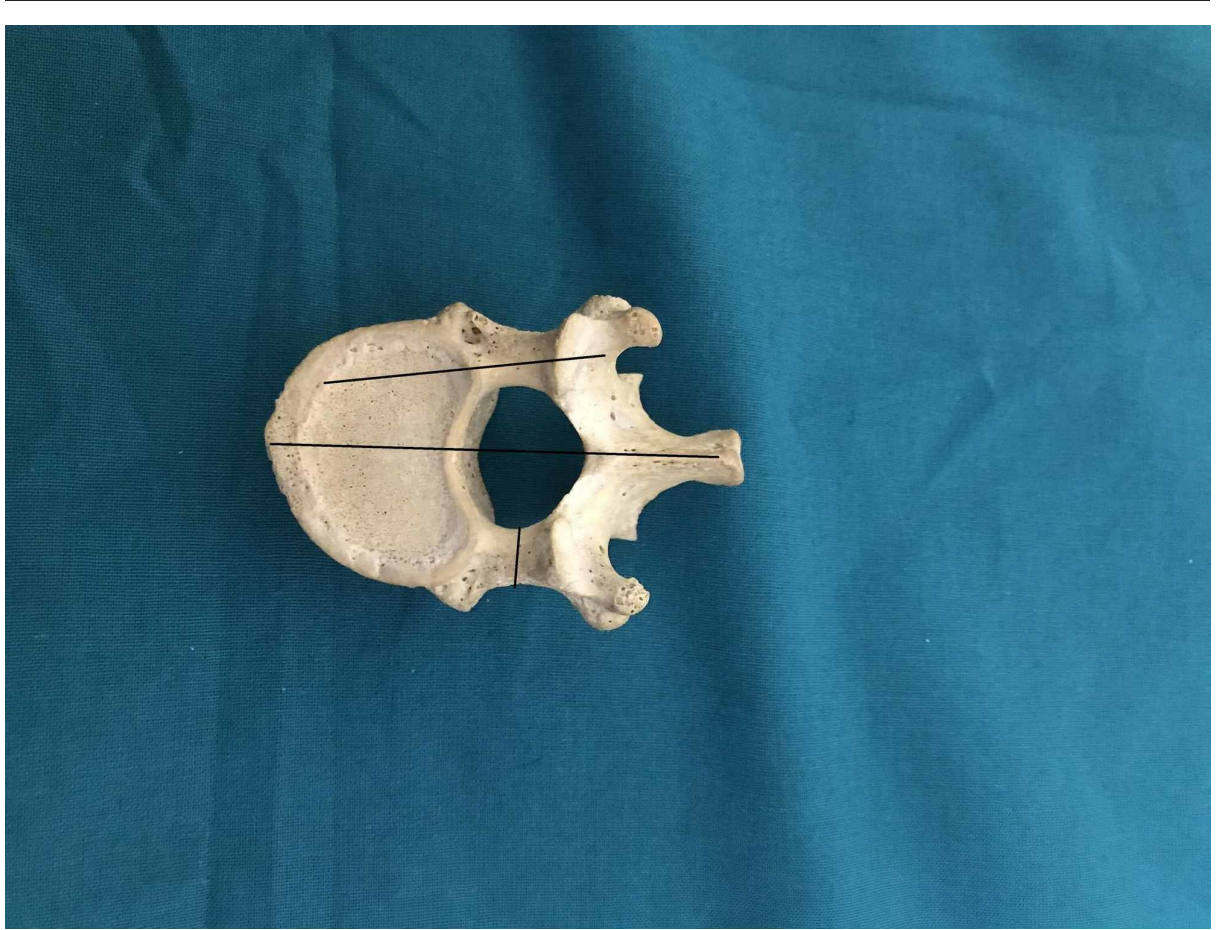




\section{Cureus}

\section{FIGURE 3: Transverse pedicle angle and pedicle width}

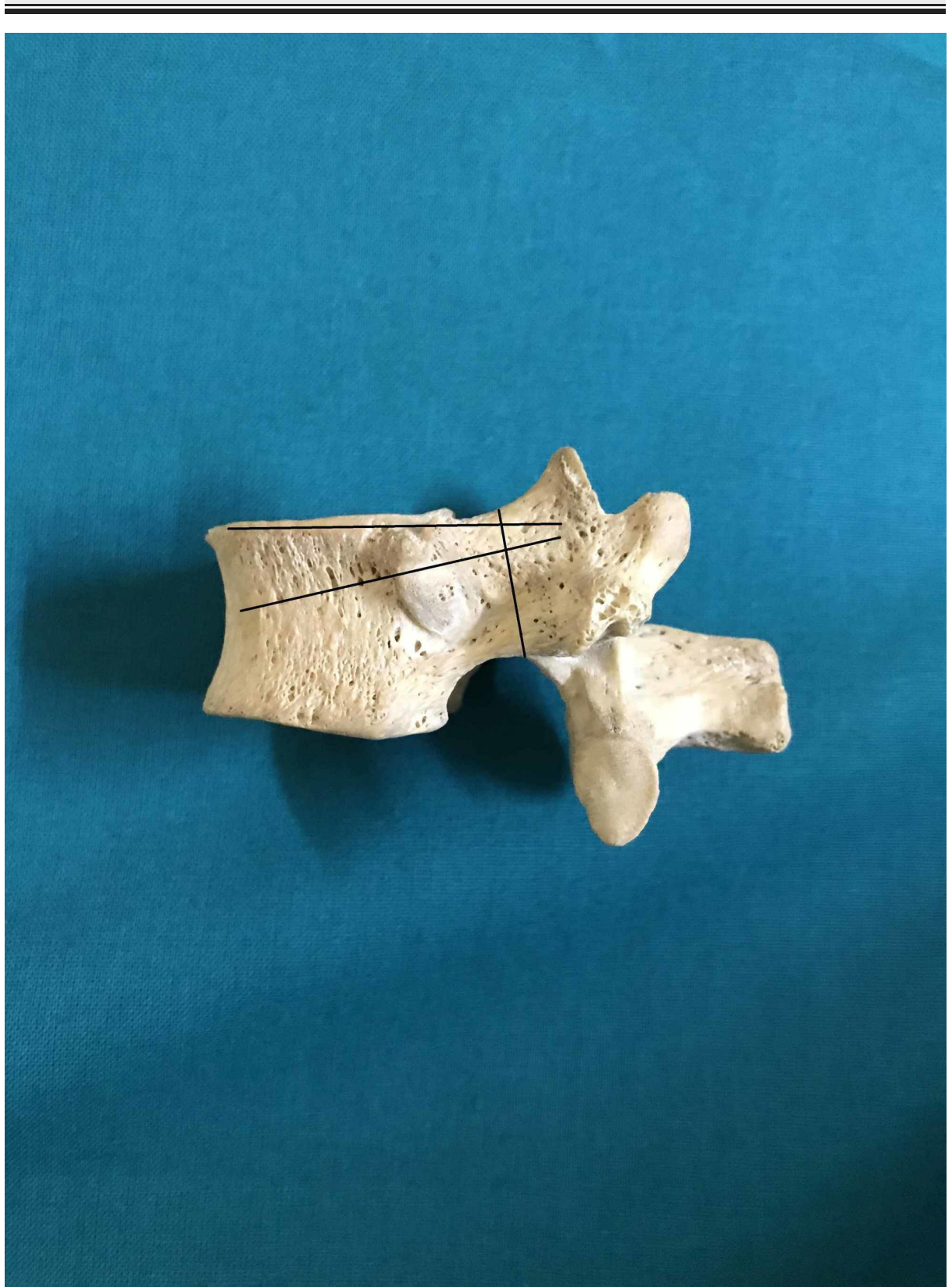

FIGURE 4: Sagittal angle and pedicle height

\section{Statistical analysis}

The measurements were tabulated, and the data were analyzed using the Excel 2010 program (Microsoft ${ }^{\circledR}$, Redmond, Washington, USA). Numerical variables were summarized using mean and standard deviation.

\section{Results}

Both pedicle width and pedicle height varied between individual vertebral columns and between levels, although these dimensions did not differ significantly between the right and left sides.

Pedicle width (transverse external diameter) - decreased progressively from T1 to T5 levels and then increased gradually to T12 level. Among all the thoracic vertebrae, T12 was found to have the widest pedicle width (mean $7.89 \pm 0.70 \mathrm{~mm}$ ); whereas, the narrowest pedicle width was at $\mathrm{T} 5$ (mean $3.65 \pm 0.40 \mathrm{~mm}$ ) (Table 1). 


\section{Cureus}

Pedicle height (sagittal external diameter) - was narrowest at T1 level (mean $8.77 \pm 0.69 \mathrm{~mm}$ ) and it progressively increased up to the T12 level (mean $15.45 \pm 0.78 \mathrm{~mm}$ ) and it was maximum at that level for the thoracic spine (Table 2).

The transverse angle of pedicle - a constant decrease in transverse angle of pedicles was observed from T1 to T12 level. The highest angle was seen at T1 (mean $30.37 \pm 2.56$ degree) and least at T12 (mean $7.19 \pm 0.87$ degree) (Table 3).

The sagittal angle of pedicle - T2 was observed to have the highest sagittal angle (mean $19.22 \pm 2.24$ degree) while the least sagittal angle was observed at T12 (mean $9.55 \pm 0.88$ degree) (Table 4 ).

\begin{tabular}{|c|c|c|c|c|c|c|c|c|c|}
\hline & $\begin{array}{l}\text { Datir \& Mitra } \\
\text { [10] }\end{array}$ & $\begin{array}{l}\text { Hou et al. } \\
\text { [11] }\end{array}$ & $\begin{array}{l}\text { Scoles et al. } \\
\text { [12] }\end{array}$ & $\begin{array}{l}\text { Chaynes et } \\
\text { al. [13] }\end{array}$ & $\begin{array}{l}\text { Vaccaro et } \\
\text { al. [14] }\end{array}$ & $\begin{array}{l}\text { Kim et al. } \\
\text { [15] }\end{array}$ & $\begin{array}{l}\text { Singh et al. } \\
\text { [16] }\end{array}$ & $\begin{array}{l}\text { Kaur et al. } \\
\text { [17] }\end{array}$ & $\begin{array}{l}\text { Current } \\
\text { study }\end{array}$ \\
\hline & (NN =18) & $(\mathrm{N}=25)$ & $(\mathrm{N}=25)$ & $(\mathrm{N}=14)$ & $(\mathrm{N}=24)$ & $(\mathrm{N}=42)$ & (N=100) & $(\mathrm{N}=50)$ & $(\mathrm{N}=20)$ \\
\hline T1 & 7.3 & & 7.3 & 8.3 & & 8.1 & 7.72 & 9.27 & 7.69 \\
\hline T2 & 6.3 & & & 6.5 & & 6.1 & 6.22 & 7.5 & 5.7 \\
\hline T3 & 5.2 & & 3.9 & 5.9 & & 4.6 & 5.03 & 6 & 4.19 \\
\hline T4 & 4.8 & & & 5.4 & 4.5 & 4.2 & 4.53 & 4.5 & 3.69 \\
\hline T5 & 4.7 & & & 4.9 & 4.4 & 4.3 & 4.22 & 5 & 3.65 \\
\hline T6 & 5 & & 3.5 & 5.1 & 4.6 & 4.7 & 4.58 & 5.5 & 3.88 \\
\hline T7 & 5.4 & & & 5.7 & 4.7 & 4.8 & 4.82 & 6 & 4.47 \\
\hline T8 & 5.4 & & & 6.4 & 5.1 & 5.1 & 4.82 & 6.32 & 4.79 \\
\hline 19 & 5.9 & 6 & 3.9 & 6.4 & 5.8 & 5.2 & 5.33 & 6.28 & 5.35 \\
\hline T10 & 6.7 & 7 & & 7.4 & 6.7 & 6.3 & 6.1 & 6.54 & 5.8 \\
\hline T11 & 8.2 & 8.6 & & 9.3 & 8 & 7.9 & 7.36 & 7.84 & 7.39 \\
\hline T12 & 8.7 & 8.8 & 7.4 & 8.9 & 7.8 & 7.9 & 7.94 & 8.31 & 7.89 \\
\hline
\end{tabular}

TABLE 1: Comparison of transverse diameter (pedicle width in $\mathrm{mm}$ ) with other studies 


\section{Cureus}

\begin{tabular}{|c|c|c|c|c|c|c|}
\hline \multirow{2}{*}{ Serial No. } & Datir \& Mitra [10] & Hou et al. [11] & Vaccaro et al. [14] & Scoles et al. [12] & Singh et al. [16] & Current Study \\
\hline & $(\mathrm{N}=18)$ & $(\mathrm{N}=25)$ & $(\mathrm{N}=8-24)$ & $(N=25)$ & $(\mathrm{N}=100)$ & $(\mathrm{N}=20)$ \\
\hline T1 & 9.4 & & & 9.2 & 8.6 & 8.77 \\
\hline T2 & 12.1 & & & & 10.58 & 10.32 \\
\hline 13 & 12.2 & & & 11.8 & 11.39 & 10.47 \\
\hline T4 & 11.8 & & 10.1 & & 11.09 & 10.43 \\
\hline 15 & 11.6 & & 10.6 & & 10.86 & 10.38 \\
\hline T6 & 11.7 & & 10.1 & 11.5 & 10.85 & 10.13 \\
\hline 17 & 12.5 & & 10.8 & & 11.2 & 10.46 \\
\hline 18 & 13.2 & & 11.1 & & $11 . / 5$ & 10.94 \\
\hline T9 & 14.4 & 12.5 & 12.3 & 12.9 & 12.81 & 12.41 \\
\hline T10 & 16.6 & 14.4 & 14.1 & & 14.22 & 13.73 \\
\hline T11 & 17.7 & 16.4 & 15 & & 15.55 & 14.94 \\
\hline T12 & 18.7 & 17.1 & 14.7 & 16 & 15.53 & 15.45 \\
\hline
\end{tabular}

TABLE 2: Comparison of sagittal diameter (pedicle height in $\mathrm{mm}$ ) with other studies

\begin{tabular}{|c|c|c|c|c|c|c|c|c|}
\hline S.No. & $\begin{array}{l}\text { Datir \& Mitra } \\
\text { [10] }\end{array}$ & $\begin{array}{l}\text { Scoles et al. } \\
\text { [12] }\end{array}$ & $\begin{array}{l}\text { Chaynes et al. } \\
\text { [13] }\end{array}$ & $\begin{array}{l}\text { Vaccaro et al. } \\
\text { [14] }\end{array}$ & $\begin{array}{l}\text { Zindrick et al. } \\
\text { [18] }\end{array}$ & $\begin{array}{l}\text { Singh et al. } \\
{[16]}\end{array}$ & $\begin{array}{l}\text { Kaur et al. } \\
{[17]}\end{array}$ & $\begin{array}{l}\text { Current } \\
\text { Study }\end{array}$ \\
\hline & $(\mathrm{N}=18)$ & $(\mathrm{N}=25)$ & $(\mathrm{N}=14)$ & $(\mathrm{N}=24)$ & $(\mathrm{N}=42)$ & $(\mathrm{N}=100)$ & $(\mathrm{N}=50)$ & $(\mathrm{N}=20)$ \\
\hline T1 & 30 & 29.8 & 27.5 & & 27 & 31.8 & 35.4 & 30.37 \\
\hline T2 & 19 & & 17.3 & & 20 & 25.8 & 26.21 & 26.27 \\
\hline T3 & 12 & 15.3 & 13 & & 15 & 20.79 & 20.01 & 24.43 \\
\hline T4 & 6 & & 8.1 & 14 & 13 & 8.12 & 19.06 & 17.4 \\
\hline T5 & 4 & & 6.8 & 13 & 9 & 15.5 & 16 & 23.32 \\
\hline T6 & 3 & 10.2 & 6.7 & 9 & 10 & 13.06 & 14.38 & 15.84 \\
\hline $\mathrm{T7}$ & 1 & & 7.2 & 7 & 9 & 12.25 & 11.82 & 12.71 \\
\hline T8 & 1 & & 7.1 & 7 & 8 & 11.22 & 12.29 & 14.35 \\
\hline T9 & 1 & 9.2 & 0.9 & 7 & 8 & 10.09 & 11.21 & 10.96 \\
\hline T10 & 1 & & 7.7 & 4 & 5 & 8.78 & 8.7 & 8.42 \\
\hline T11 & 0 & & 0.8 & 1 & 1 & -1.4 & -2.3 & 8.07 \\
\hline T12 & 0 & 9.5 & 2 & 0 & 4 & -10.01 & -9.8 & 7.19 \\
\hline
\end{tabular}




\section{Cureus}

\begin{tabular}{|c|c|c|c|c|}
\hline S. no. & Datir \& Mitra [10] $(\mathrm{N}=18)$ & Zindrick et al. [18] $(\mathrm{N}=42)$ & Singh et al. [16] $(\mathrm{N}=100)$ & Current study $(\mathrm{N}=20)$ \\
\hline T1 & 9.6 & 12.6 & 15.03 & 14 \\
\hline T2 & 11.8 & 17.5 & 16.9 & 19.2 \\
\hline T3 & 10.4 & 17.3 & 17.6 & 16.5 \\
\hline 14 & 8.9 & 16.3 & 16.7 & 17.5 \\
\hline T5 & 9.4 & 15 & 16.2 & 15.4 \\
\hline T6 & 8.2 & 15 & 15.2 & 16.8 \\
\hline T7 & 9.2 & 15.7 & 16.2 & 14.4 \\
\hline T8 & 8.6 & 16.6 & 15.6 & 13.8 \\
\hline T9 & 7.6 & 16 & 14.8 & 12.7 \\
\hline T10 & 5.5 & 16.8 & 10.7 & 13.1 \\
\hline T11 & 6.3 & 15.4 & 7.77 & 12.4 \\
\hline T12 & 8.5 & 11.6 & 3.92 & 9.5 \\
\hline
\end{tabular}

TABLE 4: Comparison of sagittal angle (in degrees) with other studies

\section{Discussion}

The pedicles are the strongest part of a vertebra and are made up entirely of cortical bone with a small core of cancellous bone. They act as a strut to transmit forces between the vertebral body and the neural arch [14]. According to Pal and Routal who studied the role of neural arch in weight transmission using morphometric methods, the thoracolumbar spine consists of two vertical running columns which are involved in load transmission - the anterior column is formed by the vertebral body and intervertebral disc while the posterior column is formed by successive articulations of neural arch elements (facet joints, laminae, and posterior ligamentous complex) [19]. The relative magnitude of compressive force passing through the body and neural arch alters with the change of curvature at a cervicothoracic and thoracolumbar junction along the vertebral column. The transfer of compressive forces between the body and neural arch takes place through the pedicle, which acts as a beam connecting the two columns. The pedicles transmit both tensile and bending forces which include gravitational loads as well as muscular movements.

While transpedicular spinal fixation was first described by Boucher in the 1950s, it is the work of Louis, RoyCamille, and Saillant in the past four decades that trans-pedicular fixation has become a popular method of spinal instrumentation $[1,20]$. To prevent injury to the neural structures, a safe pathway through the pedicle is important. This requires thorough knowledge of the anatomy of bony as well as neural structures $[1,2]$. The rigidity and rotational stability of pedicular screw fixation systems are determined by the pull-out strength and depth of insertion into the vertebral body; the screw diameter should fill more than $70 \%$ of the pedicle diameter, the wider the screw, the stronger is the fixation [21]. Many authors have described the morphometric aspects of the thoracic spine and the details of the pedicle sizes and dimensions by means of computed tomography (CT) scan, plain radiographs, direct specimen measurement and quantitative 3dimensional anatomic techniques [6,8-10,12,13,17,19,20].

We measured the dimensions in twenty dry vertebral columns from T1 to T12 vertebrae. The levels at risk for pedicular breach were observed to be at $\mathrm{T} 3$ to $\mathrm{T} 8$ levels. The pedicle width gradually decreased from $\mathrm{T} 1$ to T5 and then, started increasing from T6 toT12 in the present study. Similar trend was also reported in other studies $[6,8,10,13,16,17]$. This pattern of change in the size of the pedicles may be due to transition from a more mobile cervicothoracic junction to a relatively fixed mid-thoracic region, and again, to a mobile thoracolumbar junction putting differential stress on the facet joints and pedicles. Since these pedicles have smaller diameters it is suggested to plan pedicle screw trajectory and size preoperatively using CT scan. Knowledge of pedicle morphometry would add to the comfort level of the spinal surgeon, especially, one who is in the early stages of his or her career.

Specific differences in the pedicle dimensions between males and females have been reported in the literature. Kim et al. reported differences in pedicle width between males and females at T10, L3, and L5 levels while Hou et al. reported differences only at T12 level, wherein the male pedicles were found to be larger $[11,15]$. We did not study the sex-differences. 
Our findings are in concurrence with other authors in that the risk of a cortical breach during pedicle screw insertion is highest from T3 to T8 levels using conventional techniques [17,21-23]. Various modifications like the 'in-out-in' technique, medial margin targeting method, pedicle or transverse process hooks, extrapedicular screw, cannulated screw, laminar screw, and the cortical bone trajectory method have been studied as safe alternatives for thoracic spine fixation [20,24-29]. Use of custom or patient-specific implants and instrumentation using additive manufacturing technology is also recommended for these levels along with computer and spinal navigation assisted spinal instrumentation, however, these have the disadvantage of increased the cost of treatment and non-availability [5,30].

In the present study, transverse pedicle angles from T1 to T10 vertebrae were found to be more compared to studies performed on Caucasians. Our findings of the pedicles being angulated medially, postero-anteriorly, decreasing in the cephalo-caudad direction from $\mathrm{T} 1$ to $\mathrm{T} 4$, increasing slightly at $\mathrm{T} 5$, and then decreasing trend from $\mathrm{T} 5$ to T12, are similar to other studies from India [10,16,17]. The Caucasian studies show a gradually decreasing trend from T1 to T12 [19]. The pedicle angulation in the transverse plane was closer to the neutral plane at T11 and T12 levels in some studies while it was 8.07o and 7.19o cephalad in the present study $[10,13,16,17]$ (Table 3).

In the sagittal plane, we found the pedicles were angulated in the cephalad direction and the angulation gradually decreased from T2 caudad; 19.220 at T2 to 9.550 at T12. These findings are comparable to studies by Datir and Mitra and Zindrick et al. who reported maximum sagittal angulation at T2 level (11.8o and 17.5o respectively) while Singh et al. reported the maximum sagittal angulation at T3 level $(17.60)[10,16,18]$

The general trend of morphological measurement of the pedicle dimensions in the present study was comparable to the findings of other authors from India, and also, to the Chinese population; these measurements were lower than those of the Caucasians $[6,10,11,20]$. These differences could be attributed to the larger physique of the Caucasians.

\section{Limitations of the study}

We recognise a few limitations of the study. Since we studied dry vertebral columns, we could not study the sex and age-related differences. Secondly, performing actual pedicle screw insertion in cadavers and looking for pedicle breach would have provided additional information. However, we could not perform this due to the lack of available intact cadaveric vertebral columns as these are used for undergraduate teaching at our institute.

\section{Conclusions}

Pedicle instrumentation in thoracic vertebrae provides little margin of safety due to its morphometric features. The anatomical variation in different population groups should be considered while using thoracic pedicle screws. The findings of our study would be of immense help to the spinal surgeons especially those in the early phase of their career in planning and placement of thoracic pedicle screws. The results of the study could help in designing implants and instrumentations specific for the thoracic spine for central Indian population aiding surgeons to perform more precise and, therefore, safe surgical procedures.

\section{Additional Information \\ Disclosures}

Human subjects: Consent was obtained by all participants in this study. Institutional Human Ethics Committee , All India Institute Of Medical Sciences , Bhopal issued approval LOP/2018/IM0206. Date of Review 21/11/2018, Decision of the committee : Approved . Animal subjects: All authors have confirmed that this study did not involve animal subjects or tissue. Conflicts of interest: In compliance with the ICMJE uniform disclosure form, all authors declare the following: Payment/services info: All authors have declared that no financial support was received from any organization for the submitted work. Financial relationships: All authors have declared that they have no financial relationships at present or within the previous three years with any organizations that might have an interest in the submitted work. Other relationships: All authors have declared that there are no other relationships or activities that could appear to have influenced the submitted work.

\section{References}

1. West JL, Ogilvie JW, Bradford DS: Complications of the variable screw plate pedicle screw fixation . Spine. 1991 May, 16:576-9. 10.1097/00007632-199105000-00016

2. Hyun S-J, Kim YJ, Cheh G, Yoon SH, Rhim S-C: Free Hand Pedicle Screw Placement in the Thoracic Spine without Any Radiographic Guidance : Technical Note, a Cadaveric Study. J Korean Neurosurg Soc. 2012 Jan, 51:66-70. 10.3340/ikns.2012.51.1.66

3. Elliott MJ, Slakey JB: Thoracic pedicle screw placement: analysis using anatomical landmarks without image guidance. J Pediatr Orthop. 2007 Aug, 27:582-6. 10.1097/01.bpb.0000279030.59150.13

4. Modi HN, Suh SW, Fernandez H, Yang JH, Song H-R: Accuracy and safety of pedicle screw placement in neuromuscular scoliosis with free-hand technique. Eur Spine J Off Publ Eur Spine Soc Eur Spinal Deform 
Soc Eur Sect Cerv Spine Res Soc. 2008 Dec, 17:1686-96. 10.1007/s00586-008-0795-6

5. Rajasekaran S, Vidyadhara S, Ramesh P, Shetty AP: Randomized clinical study to compare the accuracy of navigated and non-navigated thoracic pedicle screws in deformity correction surgeries. Spine. 2007 Jan, 15:56-64. 10.1097/01.brs.0000252094.64857.ab

6. Acharya S, Dorje T, Srivastava A: Lower dorsal and lumbar pedicle morphometry in Indian population: a study of four hundred fifty vertebrae. Spine. 2010 May 1, 35:378-384. 10.1097/BRS.0b013e3181cb7f2b

7. Chadha M, Balain B, Maini L, Dhaon BK: Pedicle morphology of the lower thoracic, lumbar, and S1 vertebrae: an Indian perspective. Spine. $2003 \mathrm{Apr}$, 15:744-9.

8. Nojiri K, Matsumoto M, Chiba K, Toyama Y: Morphometric analysis of the thoracic and lumbar spine in Japanese on the use of pedicle screws. Surg Radiol Anat SRA. 2005 Apr, 27:123-8. 0.1007/s00276-004-0305-4

9. Christodoulou AG, Apostolou T, Ploumis A, Terzidis I, Hantzokos I, Pournaras J: Pedicle dimensions of the thoracic and lumbar vertebrae in the Greek population. Clin Anat N Y N. 2005 Sep, 18:404-8. 10.1002/ca.20155

10. Datir SP, Mitra SR: Morphometric study of the thoracic vertebral pedicle in an Indian population . Spine (Phila Pa 1976. 2004, 29:1174-1181. 10.1097/00007632-200406010-00004

11. Hou S, Hu R, Shi Y: Pedicle morphology of the lower thoracic and lumbar spine in a Chinese population. Spine. 1993 Oct 1, 18:1850-5. 10.1097/00007632-199310000-00021

12. Scoles PV, Linton AE, Latimer B, Levy ME, Digiovanni BF: Vertebral body and posterior element morphology: the normal spine in middle life. Spine. 1988 Oct, 13:1082-6. 10.1097/00007632-19881000000002

13. Chaynes P, Sol JC, Vaysse P, Bécue J, Lagarrigue J: Vertebral pedicle anatomy in relation to pedicle screw fixation: a cadaver study. Surg Radiol Anat SRA. 2001, 23:85-90. 10.1007/s00276-001-0085-z

14. Vaccaro AR, Rizzolo SJ, Balderston RA, Allardyce TJ, Garfin SR, Dolinskas C.: Placement of pedicle screws in the thoracic spine. Part II: An anatomical and radiographic assessment. J Bone Joint Surg Am. 1995 Aug, 77:1200-6. 10.2106/00004623-199508000-00009

15. Kim NH, Lee HM, Chung IH, Kim HJ, Kim SJ: Morphometric study of the pedicles of thoracic and lumbar vertebrae in Koreans. Spine. 1994, 19:1390-1394. 10.1097/00007632-199406000-00014

16. Singh R, Srivastva SK, Prasath CSV, Rohilla RK, Siwach R, Magu NK: Morphometric measurements of cadaveric thoracic spine in Indian population and its clinical applications. Asian Spine J. 2011 Mar, 5:20-34. 10.4184/asj.2011.5.1.20

17. Kaur K, Singh R, Prasath V, Magu S, Tanwar M: Computed tomographic-based morphometric study of thoracic spine and its relevance to anaesthetic and spinal surgical procedures. J Clin Orthop Trauma. 2016 Jun, 7:101-8. 10.1016/j.jcot.2015.12.002

18. Zindrick MR, Wiltse LL, Doornik A, Widell EH: Knight GW, Patwardhan AG, et al. Analysis of the morphometric characteristics of the thoracic and lumbar pedicles. Spine. 1987 Mar, 12:160-6. 10.1097/00007632-198703000-00012

19. Pal GP, Routal RV: Transmission of weight through the lower thoracic and lumbar regions of the vertebral column in man. J Anat. 1987 Jun, 152:93-105.

20. Puvanesarajah V, Liauw JA, Lo S-F, Lina IA, Witham TF: Techniques and accuracy of thoracolumbar pedicle screw placement. World J Orthop. 2014 Apr, 18:112-23. 10.5312/wjo.v5.i2.112

21. Cho SK, Skovrlj B, Lu Y, Caridi JM, Lenke LG: The effect of increasing pedicle screw size on thoracic spinal canal dimensions: an anatomic study. Spine. 2014 Sep, 15:1195-1200. 10.1097/BRS.0000000000000514

22. Weinstein JN, Spratt KF, Spengler D, Brick C, Reid S: Spinal pedicle fixation: reliability and validity of roentgenogram-based assessment and surgical factors on successful screw placement. Spine. 1988 Sep, 13:1012-8. 10.1097/00007632-198809000-00008

23. Chan CYW, Kwan MK, Saw LB: Thoracic pedicle screw insertion in Asian cadaveric specimen: does radiological pedicle profile affect outcome?. Surg Radiol Anat SRA. 2011 Jan, 33:19-25. 10.1007/s00276-001$0085-\mathrm{Z}$

24. Lee CS, Park S-A, Hwang CJ, Kim D-J, Lee W-J, Kim Y-T.: A novel method of screw placement for extremely small thoracic pedicles in scoliosis. Spine. 2011 Jul, 36:1112-1116. 10.1097/BRS.0b013e3181ffeea2

25. Spinal Navigation: Standard Preoperative Versus Intraoperative Computed Tomography Data Set Acquisition for Computer-Guidance System: Radiological and Clinical Study in 100 Consecutive Patients PubMed [Internet]. [cited. (2020 Apr 7]. Available from). https://pubmed.ncbi.nlm.nih.gov/21304425/.

26. Husted DS, Yue JJ, Fairchild TA, Haims AH: An extrapedicular approach to the placement of screws in the thoracic spine: an anatomic and radiographic assessment. Spine. 2003 Oct, 15:2324-30. 10.1097/01.BRS.0000085361.32600.63

27. Lee CK, Chan CYW, Gani SMA, Kwan MK: Accuracy of cannulated pedicle screw versus conventional pedicle screw for extra-pedicular screw placement in dysplastic pedicles without cancellous channel in adolescent idiopathic scoliosis: a computerized tomography (CT) analysis. Eur Spine J Off Publ Eur Spine Soc Eur Spinal Deform Soc Eur Sect Cerv Spine Res Soc. 2017, 26:2951-60. 10.1007/s00586-017-5266-5

28. Müller J, Müller J-U, Koppe T, Nowak S, Schroeder HWS, Baldauf J: A radiological and anatomic examination of intralaminar screws in the thoracic spine-a theoretical feasibility study. Acta Neurochir :2229-36. 10.1007/s00701-018-3678-6

29. Matsukawa K, Yato Y, Hynes RA, Imabayashi H, Hosogane N, Asazuma T.: Cortical Bone Trajectory for Thoracic Pedicle Screws: A Technical Note. Clin Spine Surg. 2017 Jun, 30:497-504. 10.1097/BSD.0000000000000130

30. Sugawara T, Higashiyama N, Kaneyama S, Takabatake M, Watanabe N, Uchida F.: Multistep pedicle screw insertion procedure with patient-specific lamina fit-and-lock templates for the thoracic spine: clinical article. J Neurosurg Spine. 2013 Aug, 19:185-90. . 10.3171/2013.4.SPINE121059 